\title{
Önreflexiót támogató mentor tanári eszközök és módszerek
}

\section{Bevezetés}

Tanítói pályafutásom alatt többször nyílt lehetőségem, hogy pályakezdő kollégáknál, főiskolai hallgatóknál lássak el „mentori” feladatokat. A tanítás tanulása, illetve tanítása során is fontos kérdés, hogy milyen módszereket és eszközöket használunk. Ezért is választottam kutatásom témáját, mert törekszem arra, hogy megismerjek újabb módszereket és változatos korszerü eszközöket, amiket a rám váró mentorálási folyamatokban hasznosítani tudok. Kutatómunkám itt ismertetett részében törekedtem az önreflexiót támogató módszerek bemutatására, illetve választ kapni arra, hogy mennyire ismerik és használják a pedagógusjelöltek és pályakezdő pedagógusok ezeket a módszereket. Napjainkban igen fontos kérdés, hogy azok a pedagógusok, akik közvetítőjük lesznek hivatásuknak, mindent megtegyenek annak érdekében, hogy a pályakezdőkben ne alakuljon ki az esetleges pályaelhagyás gondolata. Képesek legyenek felkelteni a kíváncsiságot, hogy a pályakezdők megtapasztalhassák ennek a hivatásnak a lényegi üzenetét, hogy emberekkel, gyerekekkel foglalkozni, nemes és szép feladat.

\section{Rövid elméleti háttér}

A reflektív gondolkodás tudatos alkalmazásához elengedhetetlen az önelemzőképesség, nyitott gondolkodás képessége, hajlandóság a több szempontú elemzésre. Tapasztalat szerint sokan idegenkednek az önreflexió tudatos alkalmazásától, pedig a tudásalapú társadalmunkban állandó célként jelenik meg a teljesítmény javítása a szakmai fejlődés igénye, mely elvárásoknak nem tudunk megfelelni, ha nem alkalmazzuk a reflektív gondolkodást. A pedagógusi munka elképzelhetetlen helyes önreflexió nélkül. Önreflexióra való képességgel azonnal segíthető a pálya sikeressége az alkalmazott oktatási módszerek hatékonysága. Megerősítés szerezhető általa a végzett munkáról, illetve rávilágít a fejlesztendő területekre.

Az önreflexió nem csak a szakmai fejlődésben játszik fontos szerepet, de nyugodtan mondható, hogy az élet minden területén jelen kell, hogy legyen. Ismétlődő alkalmazásával egészségvédő szerepet is betölt, összefüggésben áll a testi, lelki fizikai erőnlétünkkel. Egy prevenciós lehetőség módszerének is tekinthetjük a pedagógus kiégéssel szemben.

Hunya Mária tanulmányában rámutat, hogy „a szakmai reflexió szándékos, céltudatos, strukturált, az elméletet és a gyakorlatot összekapcsoló, tanulással kapcsolatos, a változást és a fejlődést célzó, egy bizonyos cél elérésére irányuló gondolkodás. ${ }^{1}$ A reflektív gondolkodás egy olyan módszernek mondható, amely a pedagógus egész pályáján jelen kell, hogy legyen. Szivák Judit szerint „,...reflektív tanításon olyan, a pedagógiai tevékenységet folyamatosan és tudatosan elemző gondolkodást és gyakorlatot értünk, mely biztosítja az oktató-nevelő tevékenység folyamatos önellenőrzését és ezen alapuló fejlesztését."2

\footnotetext{
${ }^{1}$ http://bit.ly/1E5o4aC

${ }^{2}$ Szivák Judit: A reflektív gondolkodás fejlesztése. Magyar Tehetségsegítő Szervezetek Szövetsége, 2010. 9. o.
} 
Fontos feladat tanítványainkban, mentorpedagógusoknak a mentoráltaknál fejleszteni ezt a képességet. Kedvezőbbnek tekinthető a helyzet, ha már a pedagógusképzés idején sem csak egyoldalú visszajelzéseket kapnának a hallgatók, hanem egyre több olyan helyzetet teremtenének, ahol az önreflexiós képességüket tudják alkalmazni. Szivák Judit szerint: „A pedagógusokkal, beleértve, a már gyakorlott pedagógusokat is, olyan eszközöket és módszereket kell megismertetni, melyek segítenek a problémák felismerésében, elemzésében, a megoldási módok kiválasztásában. Ezeknek a technikáknak az ismeretében és alkalmazásával aktív részeseivé válnak saját személyes és az egész nevelő közösség szakmai fejlődésének." ${ }^{3}$ A mentorpedagógus fontos feladata, hogy a rábízott pedagógusjelöltek és pályakezdő pedagógusok önreflexiós képességét fejlessze és kialakítsa ennek a szokásrendszerét, megerősítve ezzel a tanulási folyamatot. Az önreflexió képessége egy olyan kulcsfontosságú képesség, melynek meglétére minden pedagógusnak törekednie kell. Kiváló eszköze és módszere lehet a szakmai fejlődésnek, bármennyire is időigényesnek tűnik a használata és rendszeres alkalmazása.

Az 1. táblázatban olyan reflektív gondolkodást, önreflexiót támogató mentorálási módszerek láthatóak, melyek megismerése és alkalmazása segít fejleszteni a pedagógusjelöltek és gyakornokok önreflexiós képességét. Az alkalmazási lehetőség megjelenítése a táblázatban besötétített színnel történt. A táblázatban szereplő módszerek és eszközök forrása a Szivák Judit: A reflektív gondolkodás fejlesztése címú könyve. ${ }^{4}$

1. táblázat: Önreflexiót támogató mentori módszerek, eszközök

\begin{tabular}{|c|c|c|c|c|c|c|c|}
\hline \multirow[b]{2}{*}{ Módszerek/ eszközök } & \multicolumn{2}{|c|}{$\begin{array}{l}\text { Mentorálási } \\
\text { tevékenységek }\end{array}$} & \multicolumn{3}{|c|}{ folyamatban } & \multicolumn{2}{|c|}{ előforduló } \\
\hline & 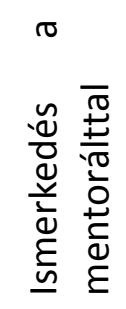 & 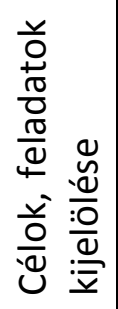 & 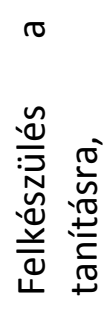 & 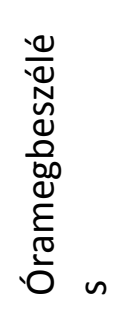 & 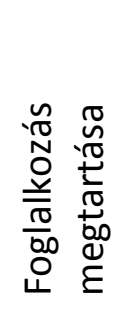 & 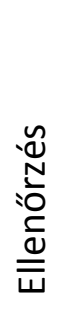 & $\frac{\frac{\mathscr{d}}{\Phi}}{\frac{\mathscr{v}}{\mathscr{d}}}$ \\
\hline \multicolumn{8}{|l|}{ Reflektív szövegelemzés } \\
\hline \multicolumn{8}{|l|}{ Kérdőív } \\
\hline \multicolumn{8}{|l|}{ Metaforatechnika } \\
\hline \multicolumn{8}{|l|}{ Fogalomtérkép } \\
\hline \multicolumn{8}{|l|}{ Dokumentumelemzés } \\
\hline \multicolumn{8}{|l|}{ Interjú } \\
\hline Hospitálási jegyzőkönyv & & & & & & & \\
\hline
\end{tabular}

\footnotetext{
${ }^{3}$ Szivák Judit: A reflektív gondolkodás fejlesztése. Magyar Tehetségsegítő Szervezetek Szövetsége, 2010. 7. o.

${ }^{4}$ Szivák Judit: A reflektív gondolkodás fejlesztése. Magyar Tehetségsegítő Szervezetek Szövetsége, 2010. 23-38.o.
} 


\begin{tabular}{|l||l|l|l|l|l|l|l|}
\hline Közös kísérletezés & & & & & & & \\
\hline Emberrajz & & & & & & & \\
\hline Támogatott felidézés & & & & & & & \\
\hline Portfólió & & & & & & & \\
\hline Reflektív napló & & & & & & & \\
\hline Reflektív modellálás & & & & & & & \\
\hline
\end{tabular}

\section{Kutatás körülményeinek rövid bemutatása}

Kutatómunka egyik alapvető célja volt, hogy feltárja a válaszadók mennyire ismerik az új pedagógiai módszereket, alkalmazzák-e az önreflexiót támogatóakat. Kutatási módszerként a kérdőíves vizsgálatot, mint primer információgyűjtési módszert választottam. A kérdőív fejlesztéséhez Szivák Judit reflektív kérdőivét vettem alapul és egészítettem ki a kutatás céljának megfelelő releváns kérdésekkel, mint például az önreflexió gyakoriságának vizsgálata a pedagógiai munka értékelésében. A minta kiválasztásának fontos szempontja az volt, hogy olyan pedagógusjelölteket kérdezzek, akik jelenleg pedagógusképzésben vesznek részt, illetve gyakornoki idejüket töltik az oktatási intézményben, azaz a mentori munka két különböző célcsoportját alkotják. Amennyiben a megkérdezettek több képzőintézményből kerülnek ki, illetve különböző oktatási intézményben dolgoznak, válaszaik jobban tükrözik az országos helyzetet. A vizsgálatban 74 személy vett részt önkéntes jelleggel. A megkérdezettek közül 12 férfi és 62 nő. A válaszadók közül 58 pedagógusjelölt közül 7 férfi és 51 nő. Közülük 20 a fővárosban, 38 vidéken tanul. A pedagógusjelöltek közül 31 tanító szakos és 27 tanár szakos. A minta a létszám és a földrajzi elhelyezkedés okán nem reprezentatív. 16 válaszadó gyakornok. A 2. táblázat mutatja a kérdezettek összetételét helyre, nemre, valamint szakra lebontva.

2. táblázat: A vizsgálatban részt vevők létszáma hely, nem, szak szerinti bontásban

\begin{tabular}{|c|c|c|c|c|c|c|}
\hline Hely & Nem & & Szak & & Pedagógusjelölt & Összesen \\
\hline \multirow[t]{4}{*}{ Föváros } & \multirow{2}{*}{ Nő } & \multirow{2}{*}{23} & tanító & 23 & 20 & \multirow{4}{*}{23} \\
\hline & & & tanár & 0 & 0 & \\
\hline & \multirow{2}{*}{ Férfi } & \multirow{2}{*}{0} & tanító & 0 & 0 & \\
\hline & & & tanár & 0 & 0 & \\
\hline \multirow[t]{4}{*}{ Vidék } & \multirow{2}{*}{ Nő } & \multirow{2}{*}{39} & tanító & 13 & 11 & \multirow{4}{*}{51} \\
\hline & & & tanár & 26 & 20 & \\
\hline & \multirow{2}{*}{ Férfi } & \multirow{2}{*}{12} & tanító & 1 & 0 & \\
\hline & & & tanár & 11 & 7 & \\
\hline \multicolumn{2}{|c|}{ Összesen: } & \multicolumn{2}{|l|}{74} & 74 & 58 & 74 \\
\hline
\end{tabular}


A kitöltés önkitöltős módszerrel történt 2014. december hónap első két hetében. A kérdőívek begyújtése után az adatok az SPSS statisztikai programmal kerültek feldolgozásra.

\section{A kutatás az alábbi hipotézisre keresi a választ:}

A pedagógusjelöltek és pályakezdő pedagógusok még nem élnek tudatosan a tanítási gyakorlatukkal kapcsolatos önreflexió gyakorlatával.

\section{Önreflexió gyakoriságának használata a pedagógiai munka értékelésében}

A tapasztalat szerint a pedagógusjelöltek és pályakezdő pedagógusok nem minden esetben tudnak felelősséggel, helyes önismeret tudatában tervezni, feladatokat végrehajtani, munkájukat értékelni. Empirikus kutatások igazolják, hogy az önreflexió elengedhetetlen a tanári munka minőségének sikerességéhez. „Az önreflexió képessége, fejlettsége számos kutatás alapján kapcsolatba hozható a tanárok munkájának sikerével, minőségével. " ${ }^{5}$ Á. Majer Anna, Czuczor Judit, Kovács Enikő, Lénárt András, Réti Mónika kutatásaiban rámutat arra, hogy „Önreflexió nélkül egyéni és szakmai fejlődés is nehezen jöhet létre, mely a pedagógusok esetében még hangsúlyozottabban érvényes szakmai előmenetelük, saját hivatástudatuk, és nem utolsó sorban, a tanulók minél sikeresebbé válása érdekében. A felmérés rámutat arra, hogy leginkább a pályán már több évtizede dolgozó, gyakorlottabb kollégák végzik el a tényleges és folyamatos reflexiót, előbb-utóbb a pályakezdőknél is megjelenik ez a lényeges munkafázis szakmai igényességük magasabb lépcsőfokra emelése végett." 6

Az általam készített kérdőív itt bemutatott egységében az önreflexió ismeretével és használatával kapcsolatosan történt a kutatás, a pedagógusjelöltek és a pályakezdő pedagógusok körében.

Először annak vizsgálata történt, hogy milyen mértékben jellemző a válaszadókra a saját pedagógiai munkájukkal kapcsolatos önreflexió alkalmazása. Válaszukat ötfokú Likert-skálán minősítették. A 3. táblázatban látható, hogy az egyáltalán nem és kis mértékben válaszlehetőséget senki sem jelölte. A leggyakoribb válaszként a gyakori mértékben lehetőséget választották. Az önreflexió alkalmazás gyakorisága 1-5-ig terjedő skálán átlagosan 4,28. Annak kiderítésére, hogy az ezen értékeket választók számában, van-e szignifikáns különbség, egymintás t-próba elvégzése történt. Az egymintás $t$-próba alapján ( $t=56,512$, $\mathrm{p}=0,00)$ szignifikáns különbség mutatkozott a válaszadók mennyisége között. Mivel a válaszadók 50\%-a jelölte a „gyakori mértékben” 10,8\% jelölte csupán a „közepes mértékben” válaszlehetőséget, így nagy valószínűséggel jelentős különbség e között a két érték között mutatkozott.

\footnotetext{
${ }^{5}$ Füzi Beatrix: Az önreflexió és a tanári munka minősége közötti összefüggések empirikus vizsgálata, 2012.

6 http://ofi.hu/publikacio/hazai-pedagogus-tovabbkepzesek-szerepe-es-hatasai-pedagogusok-munkajanakalakulasaban
} 
3. táblázat: Önreflexió gyakoriságának százalékos megoszlása a pedagógiai munka értékelésében a pedagógusjelöltek és a pályakezdő pedagógusok körében

\begin{tabular}{lcc}
\hline \hline Értékítélet & Válaszadó száma & Gyakoriság (\%) \\
\hline Közepes mértékben (3) & 8 & 10,8 \\
Gyakori mértékben (4) & 37 & 50 \\
Teljes mértékben $\quad$ (5) & 29 & 39,2 \\
\hline \hline
\end{tabular}

\section{Az önreflexió alkalmainak a vizsgálata}

Arra vonatkozólag, hogy mikor végeznek önreflexiót a pedagógusjelöltek és a pályakezdő pedagógusok mindennapi gyakorlatuk, illetve a tanítási gyakorlatuk során kilenc olyan kategória lett megjelölve, melyek során leginkább szükséges az önreflexió végzése saját tapasztalataim alapján. Ezen kérdés esetében a feleletadás feleletválasztással történt, több választ is meg lehetett jelölni. A válaszadók minden esetben éltek a több válasz lehetőségével. Leggyakoribb esetként választották azokat az eseteket, amikor egész másként alakultak a tevékenységeik, mint ahogyan eltervezték, majdnem ugyanennyien jelölték meg az egy feladat lebonyolítása után, illetve harmadik legtöbbet választott helyzetként a tervezés során válaszlehetőséget jelölték. Legkevésbé élnek az önreflexió módszerével, amikor konfliktusba kerülnek egy kollégával, illetve egy feladat lebonyolítása közben. Az önreflexió alkalmának a megjelölését a 1. ábra szemlélteti.

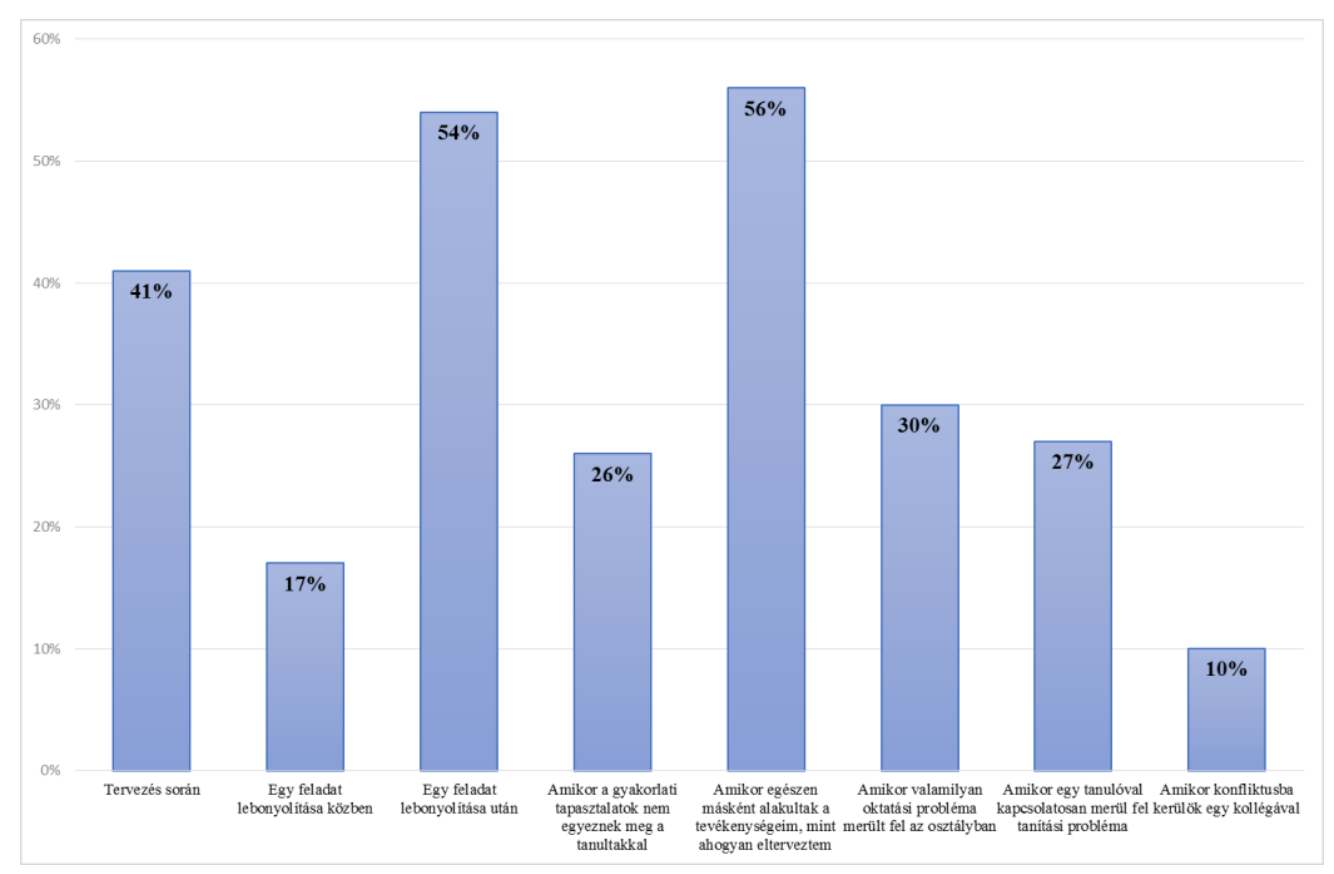

1. ábra: Az önreflexió alkalmának a megjelölése a mindennapi gyakorlat, illetve a tanítási gyakorlat során 


\section{Rendszeres önreflexió hiányának okai}

A vizsgálat kitért arra is, hogy milyen magyarázó tényezők játszanak közre abban, ha nem rendszeres az önreflexió. Legtöbben a túlterheltségre és az időhiányra hivatkozva nem végeznek önreflexiót. Legkevesebben, közel azonos százalékban, a nem tartják fontosnak a munkájuk eredményességéhez illetve, az egyéb kategóriát választották, ahol sajnos nem éltek a nyílt válasz lehetőségével, így ezek az egyéb okok nem kerültek megnevezésre. Az itt kapott értékek a 2. ábrán kerülnek szemléltetésre.

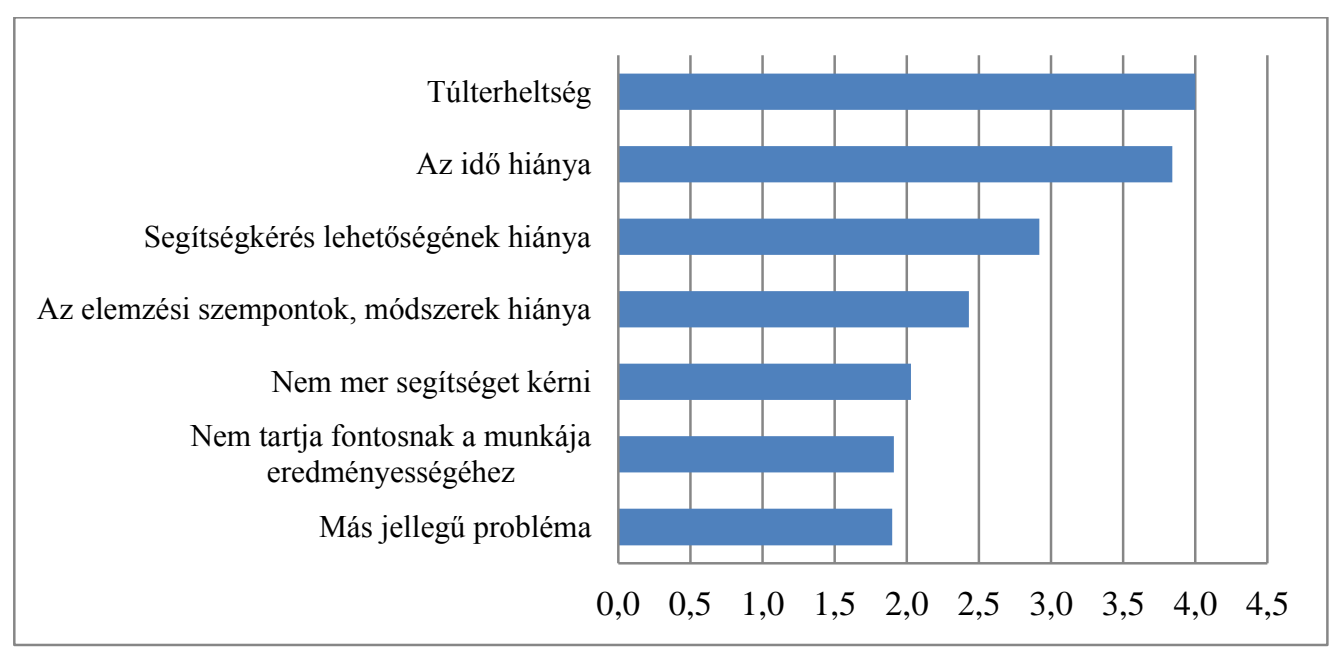

2. ábra: A rendszeres önreflexió hiány okainak átlaga

Minden napi tapasztalatok és a kollégáimmal folytatatott beszélgetések leginkább a fent bemutatott vizsgálati eredményt erősítik, miszerint a rendszeres önreflexió az időhiányra hivatkozva hiúsul meg. Sokkal inkább igyekszik mindenki a kötelező adminisztrációs feladatokat teljesíteni és azok végeztével, már nem biztos, hogy tud időt szakítani az önreflexió alkalmazására.

\section{Önreflexióhoz jól használható módszerek alkalmazásának a vizsgálata}

A kérdőív további kérdésében olyan módszerek kerültek összegyüjtésre, melyek sikeresen használhatóak önreflexió fejlesztéséhez. A kérdés arra irányult, hogy a pályakezdők és pedagógusjelöltek mennyire élnek ezeknek a módszereknek a lehetőségeivel. Továbbá ezek a módszerek, a beszélgetés témája szerint két fő csoportba lettek sorolva, az egyik a kudarcokról való beszélgetés, illetve a másik csoport a sikerekről való beszélgetés. Mindkét esetben ugyanazon potenciális beszélgetőtársak tekintetében történt vizsgálat. Vizsgáltam, hogy mennyire jellemző az előbbi két témáról való beszélgetés kollégákkal, vezetőkkel és mentorokkal. A feltett kérdésre minden megkérdezett válaszolt. Ötfokú Likert-skálán a leginkább jellemző, hogy a tanítással kapcsolatos kudarcukról beszélnek a kollégákkal. A kapott válaszok arra engednek következtetni, hogy a válaszadók többsége törekszik arra, hogy a felmerülő problémákra megoldást találjon. Felvetés szerint, aki a kudarcról beszél, az a sikereiről is beszél a kollégáival. Ennek vizsgálatára páros t-próba történt, amely igazolta a feltevést ( $t=-0,5, p=0,61)$. Ez pozitív dolognak tekinthető, hiszen ennek oka a meglévő bizalom az érintettek irányában és a megoldásra való törekvésre utal. 
A kutatás kitér annak a vizsgálatára is, hogy aki a kudarcairól beszél a kollégáival, az a vezetőivel is megbeszéli-e. Ennek vizsgálatára szintén páros t-próba történt. A páros t-próba nem igazolta a felvetést, $(t=11,11 \mathrm{p}=0,00)$. Tehát aki a kudarcairól beszél a kollégáival, az nem feltétlenül beszél ugyanerről a vezetőséggel. Van szignifikáns különbség. Ahogy a 3 . ábra mutatja, a megkérdezettek szívesebben beszélnek a kudarcaikról a kollégáikkal, mint a vezetőséggel.

Ugyanez a felvetés a sikerrel kapcsolatosan is felmerült, mely szerint annak a vizsgálata történt, hogy akik a kollégájukkal beszélnek a sikereikről, azok megbeszélik-e a vezetőjükkel is. A páros t-próba alapján, $(t=10,09, p=0,00)$ ez a felvetés is cáfolódott. Mutatkozott szignifikáns különbség, azaz a megkérdezettek a sikereikről is inkább a kollégákkal beszélnek, mint a vezetőséggel, ami szintén megmutatkozik a 3. ábrán.

A válaszadók visszajelzése alapján megállapítható, hogy a sikerről és a kudarcról is leginkább a kollégákkal és a mentorokkal beszélgetnek legszívesebben. Mindkét témában a vezetővel legkevésbé. Ennek okaként a vezetőben kialakuló vélemény hatására, az elmarasztalástól való félelem valószínűsíthető, illetve bármilyen várható negatív következmény elkerülése. A válaszok kiértékelése a 3 . ábrán látható.

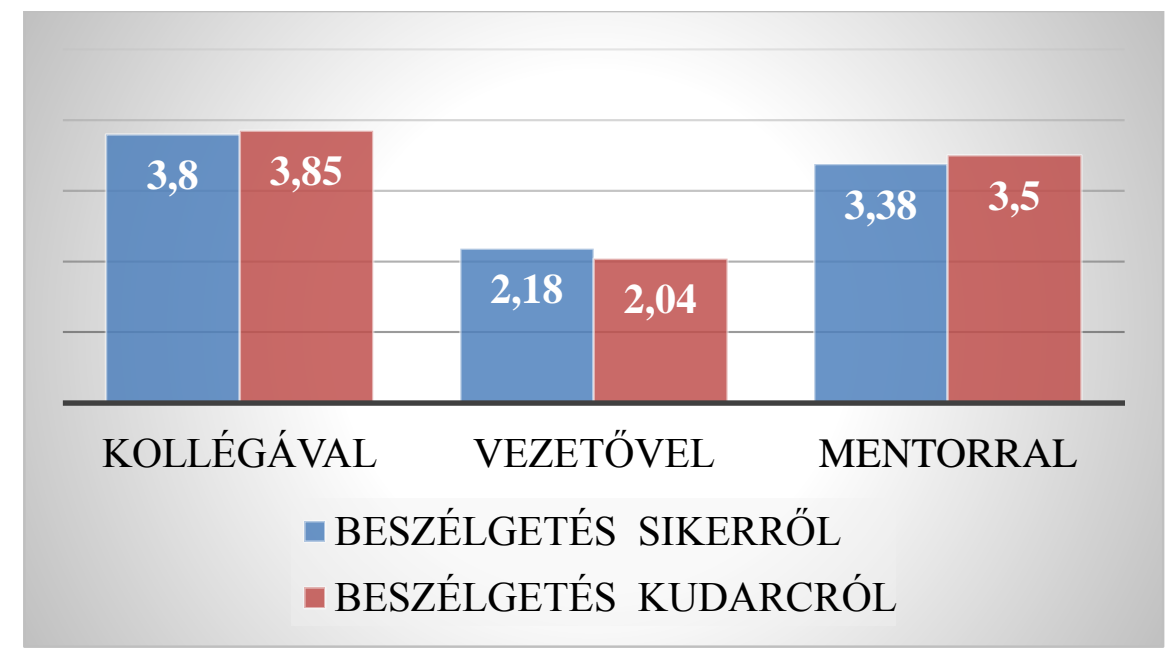

3. ábra: A kommunikáció átlagos mértéke a kollégákkal, vezetővel, mentorral

Az informális szakmai beszélgetéseknek igen fontos szerepe lehet minden tantestületben. Pozitív dolog, ha a kollégák rendszerességgel tartanak olyan összejöveteleket, mint például munkaközösségi értekezlet, tagozati megbeszélést, vagy a mentor-mentorált között tartandó rendszeres találkozókat, ahol megbeszélhetik szakmai problémáikat.

\section{Önreflexió során megfogalmazott következtetések érvényesítési szándéka}

Arra vonatkozólag, hogy törekszenek-e az önreflexió során megfogalmazott következtetéseket a későbbi munkájukban érvényesíteni, ötfokú Likert-skálán minősítették, melynek átlaga 4,61 lett. Az önreflexió által megfogalmazott következtetéseket a megkérdezettek közül 46 teljes mértékben, 27 gyakori mértékben, 1 közepes mértékben, senki sem gondolta, hogy kis mértékben, vagy egyáltalán nem törekszik a későbbi munkájában érvényesíteni. A válaszadók 62,2\%-a az ötös, 36,5\%-a négyes, 1,4\%-a hármas fokozatot jelölte meg, ennél alacsonyabb érték nem született. Az eredmények a 4. táblázatban láthatóak. 
4. táblázat: Törekvés mértéke a megfogalmazott következtetések, későbbi munkában való érvényesítésére

Értékítélet Válaszadók száma Válaszadók (\%)

\begin{tabular}{lcc}
\hline Közepes mértékben (3) & 1 & 1,4 \\
Gyakori mértékben (4) & 27 & 36,5 \\
Teljes mértékben (5) & 46 & 62,2 \\
\hline
\end{tabular}

\section{Önreflexióval kapcsolatos megállapítások vizsgálata}

Az önreflexióval kapcsolatos megállapításokat ötfokú Likert-skálán értékelték a válaszadók. A kérdés elsősorban arra irányult, hogy milyen tényezőket részesít előnyben önreflexió során, illetve mennyire átgondoltan végzi az önreflexiót, gondol-e a szándékolt és a nem szándékolt, de lehetséges következményekre. Első helyen említették átlagban 4,45 a tevékenység elemzésekor átgondolják a megoldásra váró problémák okait, a válaszadók közül 40 före teljes mértékben, 27 főre megfelelő mértékben jellemző ennek a tevékenységnek a végzése. Második helyen 4,38 átlaggal tevékenység elemzése során a tanulók teljesítményét veszik figyelembe, a válaszadók közül 39 före megfelelöen, 32 före teljes mértékben jellemző a használata a módszernek. Harmadik helyen 4,26 átlaggal tevékenységük elemzése során a tanulók reakcióit veszik figyelembe, a válaszadók közül 38 före megfelelö, 29 före teljes mértékben jellemző ennek az önelemzést támogató módszernek a használata. Legkevesebben választották 3,15 átlaggal tevékenységük elemzése során a kollégák reakcióit veszik figyelembe a válaszadók közül 24 főre mérsékelten, 19 főre megfelelő mértékben jellemző ez a tevékenység. A válaszadók önreflexióval kapcsolatos megállapítások átlagos értékeit a 4. ábra szemlélteti.

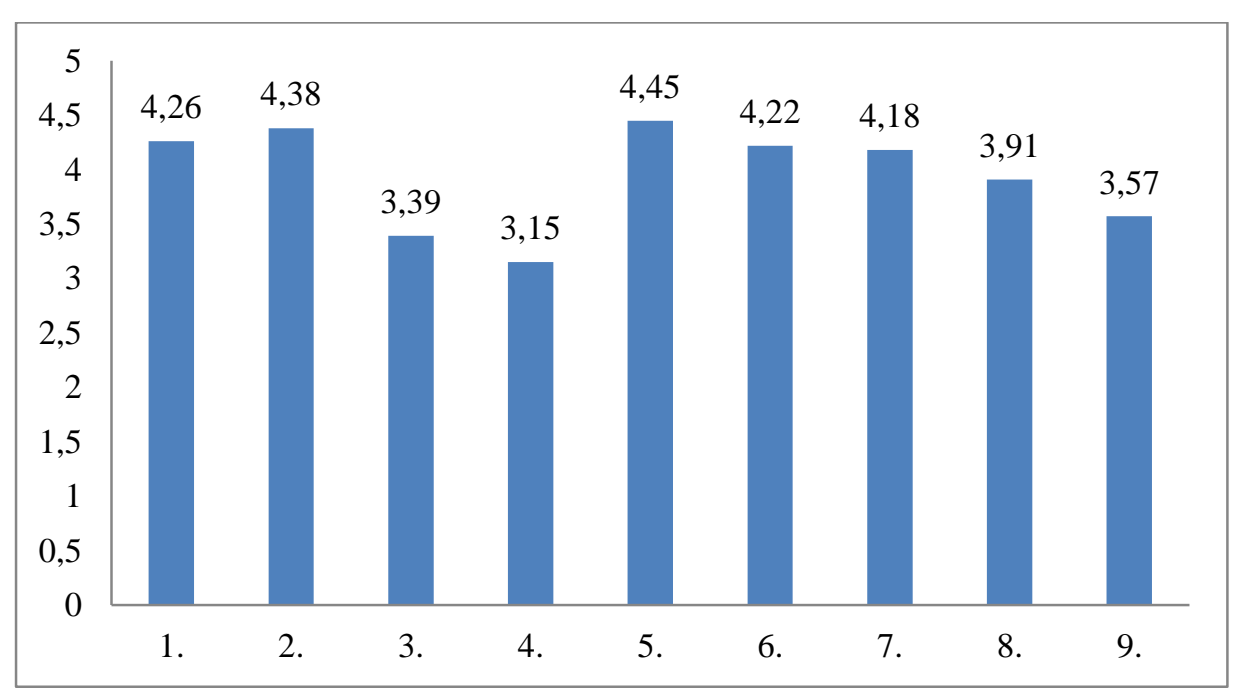

\section{4. ábra: Az önreflexióval kapcsolatos megállapítások átlagos értékei}

Jelmagyarázat: 
1. Tevékenységem elemzése során a tanulók reakcióit veszem figyelembe.

2. Tevékenységem elemzése során a tanulók teljesítményét veszem figyelembe.

3. Tevékenységem elemzése során a saját sikereimet veszem figyelembe.

4. Tevékenységem elemzése során a kollégák, (csoporttársak) reakcióit veszem figyelembe.

5. Tevékenységem elemzésekor átgondolom a megoldásra váró probléma okait.

6. Tevékenységem elemzésekor átgondolom a korábbi, hasonló problémahelyzetek megoldásait.

7. Tevékenységem elemzésekor, problémahelyzetekben általában többféle megoldási módot gondolok át.

8. Problémahelyzet megoldásakor átgondolom a szándékolt következményeket.

9. Problémahelyzet megoldása előtt átgondolom a nem szándékolt, de lehetséges következményeket.

\section{Kutatás eredményeinek összegzése}

A kutatómunka célul túzte ki, hogy képet kapjunk arról, hogy a pedagógusjelölteknek és pályakezdő pedagógusoknak milyen módszertani ismereteket sikerült elsajátítani a képzés és a gyakorlat során. Mely területeket kell fejleszteni, hogy a pedagógussá válás folyamata sikeres legyen. A felmérést kérdőív összeállítása előzte meg. A hipotézis vizsgálata az adatok statisztikai elemzésének vizsgálatával történt.

Igazolódni látszik a hipotézisben megfogalmazott felvetés, miszerint a pedagógusjelöltek és pályakezdő pedagógusok még nem élnek tudatosan a tanítási gyakorlatukkal kapcsolatos önreflexió gyakorlatával. A megkérdezettek legkevésbé ismert és használt módszerek között említették az önreflexiót támogató módszereket, mint például az önértékelés, reflektálás, reflektív modellálás. Nagyon fontos feladatnak tekinthető ezen, módszerek még mélyrehatóbb megismerése, hogy minden gyakorló pedagógus mindennapi munkájának részei legyenek. Különösen fontos ez a pályakezdők és gyakornokok esetében, akik még kevés pedagógiai tapasztalattal rendelkeznek, tehát esetükben még fontosabbnak mondható az alkalmazása. A képzőintézeteknek és a mentorpedagógusoknak nagy a felelőssége e területen. Mentorpedagógusként kiemelt szerepe lehet a pozitív példaadásnak. Folyamatos visszajelzéseik bátorítólag hathatnak a mentorált tevékenységeire. Vegyük figyelembe a mentoráltak egyéni szükségleteit, erősítsük a pozitív attitűdöket. A tanulási eredmények értékelésébe mindenképp vonjuk be a mentoráltakat és alakítsuk ki az önértékelés igényét, képességét.

Személyes tapasztalatként elmondhatom, amióta a kutatási témámmal foglalkoztam a saját szemléletem is megváltozott az önreflexióval kapcsolatosan. Egy kicsi önnevelést végeztem és folyamatosan szembeállítottam magamat a témában szerzett új információkkal. Igyekeztem tudatosan átgondolni az elém táruló pedagógiai szituációkat, a tanítási folyamatokban jelentkező helyzeteket. Több figyelmet fordítottam az önreflexiós képességeket támogató módszerek és eszközök használatára minden területen, többek között a mentori munkám során is. A kutatómunka végeztével érzékenyebb lettem a körülöttem lévő eseményekre. Természetesen nem csak a munkámban. Először valóban nehéznek tűnt önmagamat minden esetben reálisan látni és néha azt gondoltam, hogy nem lesz rá elég időm. Amikor viszont kezdtem megtapasztalni a pozitív hatásokat egyre inkább azt éreztem, hogy saját felelősségemnek kell tekinteni, hogy igen is éljek ezzel a személyiségfejlesztő és szakmai fejlődést szolgáló módszerrel. 


\section{Felhasznált irodalom}

- Bárdossy lldikó- Dudás Margit: Pedagógiai nézetek. Pécsi Tudományegyetem, Pécs, 2011. http://bit.ly/1mD3fla

- Dudás Margit: Pedagógusjelöltek belépő nézeteinek feltárása. Kódex Nyomda Kft., Pécs, 2006

- Dudás Margit: Szakmai önismeret és önreflexió a pedagógiai munkában. Pécsi Tudományegyetem BTK, 2013.

- Falus Iván - Ollé János: Statisztikai módszerek pedagógusok számára. Okker Kiadó, Budapest, 2000

- Falus Iván (szerk.): A pedagógusok pedagógiája. Nemzeti Tankönyvkiadó, Budapest, 2001. 232-260.

- Fűzi Beatrix: Az önreflexió és a tanári munka minősége közötti összefüggések empirikus vizsgálata. http://bit.ly/10PIR30

- Fúzi Beatrix: Az önreflexió és a tanári munka minősége közötti összefüggések empirikus vizsgálata, 2012.

- Hunya Mária Reflektív pedagógus-reflektív gyakorlat http://bit.ly/1E5o4aC

- Kővári Istvánné: Mentorálás, reflektivitás fejlesztésének módszerei. http://bit.ly/1LbPUWW

- Lenkovics Ildikó: A tanítás tanulása. Segédanyag a gyakorlati tanításhoz. http://bit.ly/1MAPgQ3 é.n.

- Lenkovics Ildikó: A tanítás tanulása. Segédanyag a gyakorlati tanításhoz. http://bit.ly/1MAPgQ3 é.n.

- Szivák Judit: A kezdő pedagógus. In: Iskolakultúra 1999. 4. sz. 3-13. http://bit.ly/1clLZav

- Szivák Judit: A reflektív gondolkodás fejlesztése. Magyar Tehetségsegítő Szervezetek Szövetsége, 2010

- Szivák Judit: Hallgatók neveléssel kapcsolatos nézetei. In: Iskolakultúra 2003. 5. sz.88-95. http://bit.ly/1N8pzaz

- Szivák Judit: Reflektív elméletek, reflektív gyakorlatok. ELTE Eötvös Kiadó, Budapest, 2014.

- Vámos Ágnes: Metafóra a pedagógiában. Gondolat Kiadói Kör, ELTE BTK Neveléstudományi Intézet, Budapest, 2003.

Anyaggyújtés lezárva: 2015. április 25. 